\title{
An unusual cause of finger swelling
}

\author{
Andrew Fester, ${ }_{1}^{1}$ Gidado Tukur, ${ }^{1}$ Michael Paddock ${ }^{2}$
}

${ }^{1}$ Department of Infectious Diseases, Sheffield Children's NHS Foundation Trust, Sheffield, UK

${ }^{2}$ Department of Radiology, Sheffield Children's NHS Foundation Trust, Sheffield, UK

\section{Correspondence to} Dr Michael Paddock, michael. paddock@doctors.org.uk

Accepted 6 June 2017

\section{DESCRIPTION}

A 7-year-old South Asian boy was evaluated in a district general child assessment unit following a 4-week history of daily fevers with associated pain and swelling in the thumb and middle finger phalanges of the right hand. There was no history of cough, weight loss, night sweats or trauma. On examination, he appeared well with no anaemia or jaundice. There was a spindle-shaped deformity of the right thumb and middle finger, with concomitant non-tender right axillary lymphadenopathy. No other joints were affected. The rest of the physical examination was unremarkable.

Radiographs of the affected fingers demonstrated fusiform soft tissue swelling (Figure 1A) with smooth periosteal reaction (Figure 1B). Subsequent CT of the thorax demonstrated necrotic axillary (Figure 2A) and hilar lymphadenopathy (Figure 2B) with 'tree-in-bud' change in the superior segment of the left lower lobe (Figure 1C).

A Mantoux test (protein purified derivative) was positive with an induration of $30 \mathrm{~mm}$. QuantiFERON (interferon- $\gamma$ release assay) was also positive. Haemoglobinopathy screen was negative. A biopsy of the affected phalanges revealed granulomatous inflammation with the presence of necrosis and giant cells; Mycobacterium tuberculosis PCR was positive. The diagnosis of tuberculous dactylitis
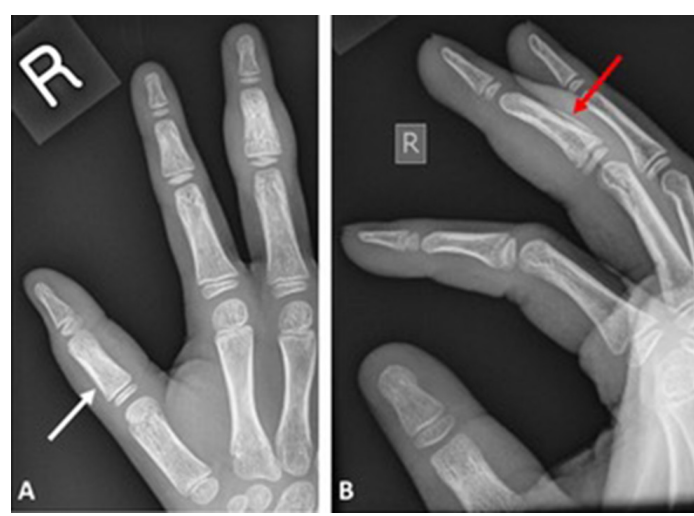

Figure 1 Cropped radiographs of the right hand. (A) Dorsoplantar projection demonstrates relative sclerosis and osseous expansion of the intermediate phalanx of the middle finger with associated fusiform soft tissue swelling and unilamellar smooth periosteal reaction of the diaphysis, best seen on the (B) lateral view (red arrows). The proximal phalanx of the thumb is affected to lesser extent with faint periosteal reaction (white arrow). Given the confirmed diagnosis of tuberculosis, radiological appearances are consistent with spina ventosa (short bone expanded with air) or tuberculous dactylitis.
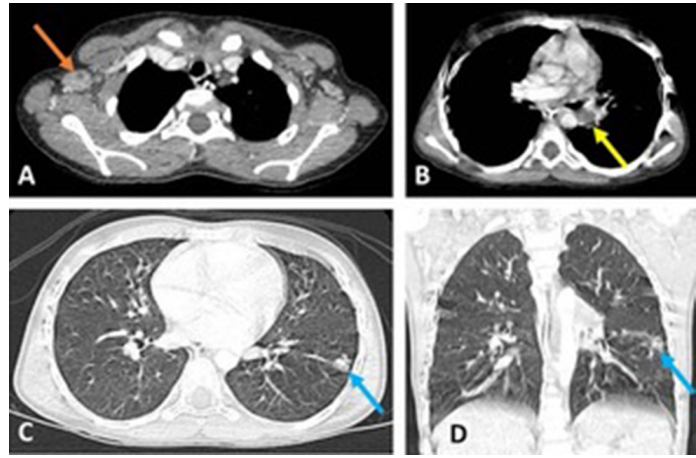

Figure 2 CT of the thorax. Selected soft tissue window axial slice $(\mathrm{A})$ demonstrates a large axillary lymph node $(22 \times 13 \mathrm{~mm})$ with an eccentric area of low attenuation consistent with necrosis (orange arrow). A more inferior axial slice (B) demonstrates a 15-mm nonenhancing low attenuation necrotic lymph node (yellow arrow). A small area of 'tree-in-bud' change in the apical segment of the left lower lobe is consistent with a Ghon focus (blue arrow), as seen on the lung window (C) axial slice and (D) coronal reconstruction. Radiological appearances are consistent with pulmonary tuberculosis.

and pulmonary tuberculosis were made given the constellation of clinical, radiological and laboratory findings: he was commenced on an appropriate antituberculosis drug regimen.

\section{Learning points}

Dactylitis, diffuse fusiform swelling of a digit(s), has a wide differential diagnosis including: ${ }^{1}$

- infectious (osteomyelitis, syphilitic and tuberculous (spina ventosa));

- haematological (sickle cell disease and leukaemia);

- arthropathic (psoriatic, hyperparathyroidism, gout and sarcoidosis).

Contributors AF: involved in the clinical care of the patient; obtained informed consent; co-wrote the manuscript text. GT: involved in the clinical care of the patient; reviewed the manuscript text. MP: extracted, reformatted and labelled all the imaging; wrote all the figure legends; co-wrote the manuscript text.

Competing interests None declared.

Patient consent Obtained from guardian.

Provenance and peer review Not commissioned; externally peer reviewed.

(C) BMJ Publishing Group Ltd (unless otherwise stated in the text of the article) 2017. All rights reserved. No commercial use is permitted unless otherwise expressly granted.

\section{REFERENCE}

1 Weerakkody Y, Desai PK. Tuberculous dactylitis. https://radiopaedia. org/articles/tuberculous-dactylitis (accessed 9 May 2017). 
Copyright 2017 BMJ Publishing Group. All rights reserved. For permission to reuse any of this content visit http://group.bmj.com/group/rights-licensing/permissions.

BMJ Case Report Fellows may re-use this article for personal use and teaching without any further permission.

Become a Fellow of BMJ Case Reports today and you can:

- Submit as many cases as you like

- Enjoy fast sympathetic peer review and rapid publication of accepted articles

Access all the published articles

- Re-use any of the published material for personal use and teaching without further permission

For information on Institutional Fellowships contact consortiasales@bmjgroup.com

Visit casereports.bmj.com for more articles like this and to become a Fellow 